\title{
Vitamin C Content of Citrus from Conventional versus Organic Farming Systems
}

\author{
A. Duarte, D. Caixeirinho, M.G. Miguel, V. \\ Sustelo and C. Nunes \\ Universidade do Algarve, CDCTPV/FCT \\ Edifício 8, Campus de Gambelas \\ 8005-139 Faro \\ Portugal
}

\author{
M. Mendes and A. Marreiros \\ Direcção Regional de Agricultura e Pescas \\ do Algarve \\ Patacão, 8000 Faro \\ Portugal
}

Keywords: antioxidant activity, clementine, fruit quality, orange, organic farming, mandarin, lemon

\begin{abstract}
Fertilization in citrus is a cultural practice with great importance as it affects significantly the quality of fruit. In this work we evaluated the effects of organic versus conventional farming systems on internal and external characteristics of citrus, with particular emphasis on vitamin $C$ content. The study was carried out in different orchards of the Algarve region, in the south of Portugal. Fruits of different orchards were harvested at physiological maturity and submitted to physical and chemical analyses. The results showed that mineral fertilization led to fruits with greater weight and diameter, a thicker peel and a more intense colour. Compared with conventional production, fruits from organic farming had more soluble solids and a lower maturation index. The highest concentrations of vitamin $C$ were recorded in fruits from organic farming, but the response depended on species and cultivar.
\end{abstract}

\section{INTRODUCTION}

During the last century, trends in food production changed from local and smallscale farms to large enterprises. Favoured by technological advances and economies of scale, large production systems turned to chemical solutions to control pests and diseases and increase soil productivity. These changes led to increased yield and external quality of horticultural products. However, pollution problems and food contamination by chemical substances became more frequent. Another consequence of this process was a greater dependence of farmers on prices of fuel, fertilizers and pesticides.

Organic farming practices offered an alternative to industrial farming. Consumers, driven by environmental and health concerns encouraged this movement (Davies et al., 1995) and caused an increased demand of organically-produced food. Surveys indicate that consumers consider organic food to be more positive for the environment and human health and more flavourful than their conventionally-grown counterparts (Bourn and Prescott, 2002).

One of the reasons why consumers prefer organic products is their supposed greater nutritional quality. However, this is not a unanimous opinion. Taking into consideration the importance gained by organic farming, surprisingly little information is available about differences in quality between fruits and vegetables produced by these two management systems. Although several reviews are available on this topic (Woese et al., 1997; Brandt and Mølgaard, 2001; Worthington, 2001; Bourn and Prescott, 2002; Bordeleau et al., 2002; Raigon, 2007), the conclusions are far from coincident. Some of the authors did not find significant differences between conventional and organic products (Bourn and Prescott, 2002); while others concluded that food produced by organic farming had a greater quality, compared to that from conventional farming systems (Woese et al., 1997; Brandt and Mølgaard, 2001; Worthington, 2001; Bordeleau et al., 2002; Raigon, 2007).

The effect of the production system on fruit quality was already studied in some citrus (Tarozzi et al., 2006; Lester et al., 2007; Pérez-López et al., 2007; Raigon, 2007; 
Beltrán-González et al., 2008). In general, citrus fruits produced in organic farms had greater juice percentage (Lester et al., 2007), and mineral (Ca, $\mathrm{Mg}, \mathrm{K}, \mathrm{Na}, \mathrm{Fe}, \mathrm{Cu}, \mathrm{Mn}$ and $\mathrm{Zn}$ ) concentration in the juice (Pérez-López et al., 2007) than those produced by conventional farming systems.

If organic citrus were to have a greater vitamin $\mathrm{C}$ concentration, it might be an important factor to increase demand of fruits from this management system. Vitamin $\mathrm{C}$ may act as antioxidant or as agent that contributes to anticarcinogenic or cardioprotective properties (Rice-Evans et al., 1996; Rapisarda et al., 1999). Considering the relatively large consumption, citrus may be highlighted as an important source of vitamin $\mathrm{C}$. This vitamin is also considered as a very important water-soluble antioxidant as it protects compounds in extracellular and intracellular spaces in most biological systems, and reduces tocopherol radicals back to their active form at the cellular membranes. It can also directly scavenge superoxide radicals, singlet oxygen, hydrogen peroxide and hydroxyl radicals (Kaur and Kapoor, 2001; Klimczak et al., 2007).

A greater vitamin $\mathrm{C}$ content in citrus from organic compared with conventional farming systems was reported by Tarozzi et al. (2006) for the red orange cultivar 'Tarocco', by Lester et al. (2007) for the grapefruit cultivar 'Rio Red' and by Raigón (2007) for the mandarin cultivars 'Nules' and 'Okitsu' and orange cultivars 'Newhall' and 'Navelina'. In the present work, we compared 18 different citrus types grown either in organic or conventional (integrated) farming, under similar environmental conditions, to investigate the influence of species or cultivar on the response to these two management systems.

\section{MATERIALS AND METHODS}

Citrus analyzed were: 'Valencia late', 'Baía', 'Dalmau', 'Newhall', 'Lanelate' and 'Rohde' oranges; 'Fina', 'Hernandina', 'Fortune', 'Fremont', Ortanique', 'Tangera' 'Setubalense', 'Nules' and 'Nova' mandarin or mandarin type cultivars; two hybrids between Citrus deliciosa and Citrus nobilis ('Encore' and 'Wilking') and the 'Lisboa' lemon. Each cultivar was sampled in triplicate (at least 20 fruits per replicate), at commercial maturity, from an organic orchard and in a conventional orchard with integrated productions practices. Paired orchards were located close to each other, with trees grafted on the same rootstock and of about the same age to allow a valid comparison of organic versus conventional fruits.

All orchards considered as organic farming were managed according to statutory European Union regulations regarding organic farming. In some organic orchards there was no application of fertilizers in the last five years, while in others fertilization was carried out with authorized fertilizers. In conventionally managed orchards, mineral fertilizers were applied all throughout the vegetative cycle of the trees.

Fruit samples were submitted to physical and chemical analyses within 24 hours after harvest. Fruits were weighed and measured individually. Juice extraction was done by using a hand operated juice extractor. After extraction, juice was filtered and the sugar content and acidity were determined by refractometry and titration, respectively. Part of the filtered juice was immediately cooled and stored at $-20^{\circ} \mathrm{C}$ until ascorbic acid analyses were made. Ascorbic acid (vitamin C) was measured as described previously (Miguel et al., 2006), by HPLC (Beckman) equipped with a System Gold Programmable Detector Module 166-UV-Vis (Beckman Coulter, USA), using a Purospher RP-18 column $(25 \mathrm{~cm}$ x $0.4 \mathrm{~cm} ; 5 \mu \mathrm{m}$ particle size). The mobile phase was $20 \mathrm{mM} \mathrm{NaH} \mathrm{PO}_{4}$ (pH 2.7 with ortophosphoric acid), with a flow rate of $1 \mathrm{ml} / \mathrm{min}$. The volume of each injection was $20 \mu 1$. Detection was performed at $210 \mathrm{~nm}$.

The data were subjected to analysis of variance (ANOVA) and means were compared by using a t-test.

\section{RESULTS AND DISCUSSION}

The overall average of all cultivars showed that in general mineral fertilization provided a greater weight and diameter of the fruits, which had a thicker peel and a more 
intense colour (Table 1). Compared with conventional farming, fruits from organic farming were more acid and had a greater ${ }^{\circ}$ Brix (Table 1 ). This may be explained, at least in part, by the fact that in some organic orchards there was no application of fertilizers for the last five years. However there are other factors that may also affect the plant composition and consequently its nutritional value, such as genetic factors (plant crop and cultivar), environmental conditions (climate, soil type, structure and microbial populations), other management practices, postharvest methodologies, etc (Woese et al., 1997; Lee and Kader, 2000; Bourn and Prescott, 2002).

Vitamin C (ascorbic acid) concentration in the juice was generally higher in fruits produced in the organic orchards (Table 1). However, this difference was not detected in all citrus cultivars included in this study. In 'Valencia late' and 'Baía' oranges the concentration of ascorbic acid was higher in the juice of the fruits from organic farming, but in other orange cultivars ('Dalmau', 'Newhall', 'Lanelate' and 'Rohde') no differences were detected between the fruits from different production systems (Fig. 1).

Some of the mandarin or mandarin type cultivars ('Fina', 'Hernandina', 'Fortune', 'Fremont', Ortanique' and 'Tangera') had higher ascorbic acid concentration in the organic farming fruits, but in the two hybrids between Citrus deliciosa and Citrus nobilis ('Encore' and 'Wilking') the opposite was true. No statistically significant differences were detected in 'Setubalense', 'Nules' and 'Nova' mandarins, as well as in 'Lisboa' lemon. Our results do not contradict those obtained previously with 'Rio Red' grapefruit and 'Tarocco' red oranges, but show that enhanced vitamin C content is not always associated with organic farming, but depends strongly on citrus species and cultivar. Carbonaro et al. (2002) found an increase in ascorbic acid content in peaches from organic farming but no differences were found in pear, showing that this observation may be valid for other types of fruit.

Under soil, climate and agronomic conditions of the Algarve, our results show the citrus cultivars which are better producers of vitamin $\mathrm{C}$ when grown in organic farming.

\section{CONCLUSIONS}

Compared with conventional production, fruits from organic farming had more soluble solids and a lower maturation index. The highest concentrations of vitamin $\mathrm{C}$ were recorded in fruits from organic farming, but the response depended on species and cultivar.

\section{ACKNOWLEDGEMENTS}

Thanks to Qta da Figueirinha, Qta da Barragoa, FRUTALGARVE and CITRIPOR for providing the fruits. We thank also Dr. Denise Martins for technical support. This work was supported by two research projects: Agro n ${ }^{\circ} 282$ - Horticulture in Organic farming; Interreg III - CITRISAUDE SP5, P120/03 - Cooperação Transfronteiriça "Citrisaude - New post-harvest technologies to improve quality and safety in citrus".

\section{Literature Cited}

Beltrán-González, F., Pérez-López, A.J., López-Nicolás, J.M. and Carbonell-Barrachina, A.A. 2008. Effects of Agricultural Practices on Instrumental Colour, Mineral Content, Carotenoid Composition, and Sensory Quality of Mandarin Orange Juice, cv. Hernandina. J. Sci. Food Agric. 88:1731-1738.

Bordeleau, G., Myers-Smith, I., Midak, M. and Szeremeta, A. 2002. Food Quality: A Comparison of Organic and Conventional Fruits and Vegetables. Ecological Agriculture - Den Kongelige Veterinoer- og Landbohøjskole, Dinamarca.

Bourn, D. and Prescott, J. 2002. A Comparison of the Nutritional Value, Sensory Qualities, and Food Safety of Organically and Conventionally Produced Foods. Crit. Rev. Food Sci. 42:1-34.

Brandt, K. and Mølgaard, J.P. 2001. Organic Agriculture: Does it Enhance or Reduce the Nutritional Value of Plant Foods?. J. Sci. Food Agric. 81:924-931.

Carbonaro, M., Mattera, M., Nicoli, S., Bergamo, P. and Cappelloni, M. 2002. 
Modulation of antioxidant compounds in organic vs conventional fruit peach (Prunus persica L.), and pear (Pyrus communis L.). J. Agric. Food Chem. 50:5458-5462.

Davies, A., Titterington, A.J. and Cochrane, C. 1995. Who buys organic food? A Profile of the Purchasers of Organic food in Northern Ireland. Brit. Food J. 97:17-23.

Kaur, C.H. and Kapoor, H.C. 2001. Antioxidants in fruits and vegetables-the millennium's health. Int. J. Food Sci. Technol. 36:703-725.

Klimczak, I., Małecka, M., Szlachta, M. and Gliszczyńska-Świgło, A. 2007. Effect of storage on the content of polyphenols, vitamin $\mathrm{C}$ and the antioxidant activity of orange juices. J. Food Compos. Anal. 20:313-322.

Lee, S.K. and Kader, A.A. 2000. Preharvest and postharvest factors influencing vitamin C content of horticultural crops. Postharvest Biol. Tec. 20:207-220.

Lester, G.E., Manthley, J.A. and Buslig, B.S. 2007. Organic vs Conventionally Grown Rio Red Whole Grapefruit and Juice: Comparison of Production Inputs, Market Quality, Consumer Acceptance, and Human Health-Bioactive Compounds. J. Agric. Food Res. 55:4474-4480.

Miguel, G., Fontes, C., Martins, D., Neves, A. and Antunes, D. 2006. Effects of postharvest treatment and storage time on the organic acid content in Assaria and Mollar pomegranate (Punica granatum L.) fruit. Ital. J. Food Sci. 18:317-322.

Pérez-López, A.J., López-Nicolás, J.M. and Carbonell-Barrachina, A.A. 2007. Effects of Organic Farming on Minerals Contents and Aroma Composition of Clemenules Mandarin Juice, European Food Res. Technol. 225:255-260.

Raigón, M.D. 2007. Alimentos ecológicos, calidad y salud. Junta de Andalucía: Consejería de Agricultura y Pesca, Sociedad Española de Agricultura Ecológica (SEAE), Sevilla.

Rapisarda, P., Tomaino, A., Lo Cascio, R., Bonina, F., de Pasquale, A. and Saija, A. 1999. Antioxidant effectiveness as influenced by phenolic content of fresh orange juices. J. Agric. Food Chem. 47:4718-4723.

Rice-Evans, C., Miller, N.J. and Paganga, G. 1996. Structure-antioxidant activity relationships of flavonoids and phenolic acids. Free Rad. Biol. Med. 20:933-956.

Tarrozi, A., Hrelia, S., Angeloni, C., Morroni, F., Biaggi, P., Guardigli, M., Cantelli-Forti, G. and Hrelia, P. 2006. Antioxidant effectiveness of organically and non-organically grown red oranges in cell culture systems. Eur. J. of Nutr. 45:152-158.

Woese, K., Lange, D., Boess, C. and Boegl, K.W. 1997. A comparison of organically and conventionally grown foods - results of a review of the relevant literature, J. Sci. Food Agric. 74:281-293.

Worthignton, V. 2001. Nutritional quality of organic versus conventional fruits, vegetables and grains. J. Altern. Complem. Med. 7:161-173. 


\section{$\underline{\text { Tables }}$}

Table 1. Effect of organic versus conventional farming on the quality of citrus fruit.

\begin{tabular}{lccc}
\hline & Organic & Conventional & $\begin{array}{c}\text { Level of } \\
\text { Significance }\end{array}$ \\
\hline Fruit weight (g) & 123.2 & 146.7 & $\mathrm{P} \leq 0.01$ \\
Fruit equatorial diameter (mm) & 60.1 & 64.4 & $\mathrm{P} \leq 0.01$ \\
Fruit longitudinal diameter $(\mathrm{mm})$ & 56.9 & 60.9 & $\mathrm{P} \leq 0.01$ \\
Peel thickness (mm) & 2.9 & 3.5 & $\mathrm{P} \leq 0.01$ \\
Juice percentage & 41.2 & 41.6 & $\mathrm{NS}$ \\
Fruit colour: & & & \\
$\quad L$ & 61.5 & 58.9 & $\mathrm{P} \leq 0.01$ \\
$\quad a$ & 23.8 & 26.6 & $\mathrm{P} \leq 0.01$ \\
$\quad b$ & 33.8 & 32.4 & $\mathrm{P} \leq 0.01$ \\
Citrus colour index (CCI) & 12.1 & 14.8 & $\mathrm{P} \leq 0.01$ \\
SSC ('Brix) & 10.3 & 8.9 & $\mathrm{P} \leq 0.01$ \\
Juice titratable acidity (ml of citric acid/100 & 0.82 & 0.70 & $\mathrm{P} \leq 0.01$ \\
ml) & 3.70 & 3.79 & $\mathrm{P} \leq 0.01$ \\
Juice pH & 16.7 & 19.1 & $\mathrm{P} \leq 0.01$ \\
Maturity index & 40.6 & 32.4 & $\mathrm{P} \leq 0.01$ \\
Juice ascorbic acid (mg/100 ml) & & &
\end{tabular}




\section{Figures}

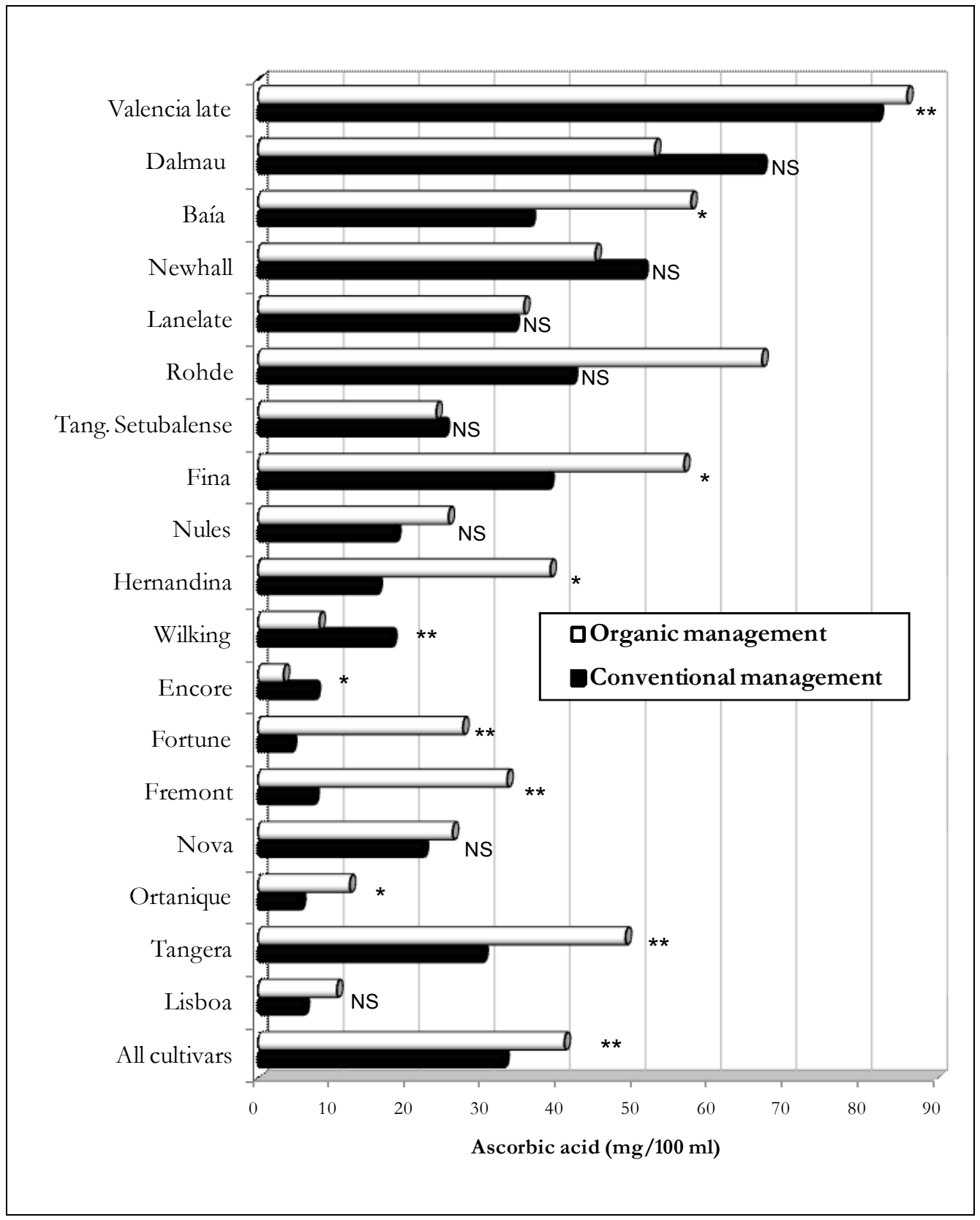

Fig. 1. Effect of organic versus conventional farming on the ascorbic acid concentration in juices of different citrus cultivars. NS - not significant; * and ** - significantly different at $\mathrm{P} \leq 0.05$ and $\mathrm{P} \leq 0.01$, respectively. 